\title{
BMJ Open Determinants Of Oral corticosteroid Responsiveness in Wheezing Asthmatic Youth (DOORWAY): protocol for a prospective multicentre cohort study of children with acute moderate-to-severe asthma exacerbations
}

\author{
F M Ducharme, ${ }^{1,2,3}$ R Zemek, ${ }^{4}$ J Gravel, ${ }^{1,3}$ D Chalut, ${ }^{5}$ N Poonai, ${ }^{6}$ S Laberge, ${ }^{1}$ \\ C Quach, ${ }^{5,7}$ M Krajinovic, ${ }^{1,2}$ C Guimont, ${ }^{8}$ C Lemière, ${ }^{9}$ M C Guertin ${ }^{10}$
}

To cite: Ducharme FM, Zemek R, Gravel J, et al. Determinants Of Oral corticosteroid

Responsiveness in Wheezing Asthmatic Youth (DOORWAY): protocol for a prospective multicentre cohort study of children with acute moderate-to-severe asthma exacerbations. BMJ Open 2014;4:e004699. doi:10.1136/bmjopen-2013004699

- Prepublication history and additional material for this paper is available online. To view these files please visit the journal online (http://dx.doi.org/10.1136/ bmjopen-2013-004699).

Received 17 December 2013 Accepted 13 February 2014

CrossMark

For numbered affiliations see end of article.

Correspondence to Dr Francine M Ducharme; francine.m.ducharme@ umontreal.ca

\section{ABSTRACT}

Introduction: Oral corticosteroids are the cornerstone of acute asthma management in the emergency department. Recent evidence has raised doubts about the efficacy of this treatment in preschool-aged children with viral-induced wheezing and in smoking adults. The aims of the study were to: (1) document the magnitude of response to oral corticosteroids in children presenting to the emergency department with moderate or severe asthma; (2) quantify potential determinants of response to corticosteroids and (3) explore the role of gene polymorphisms associated with the responsiveness to corticosteroids.

Methods and analysis: The design is a prospective cohort study of 1008 children aged $1-17$ years meeting a strict definition of asthma and presenting with a clinical score of $\geq 4$ on the validated Pediatric Respiratory Assessment Measure. All children will receive standardised severity-specific treatment with prednisone/prednisolone and cointerventions (salbutamol with/without ipratropium bromide). Determinants, namely viral aetiology, environmental tobacco smoke and single nucleotide polymorphism, will be objectively documented. The primary efficacy endpoint is the failure of emergency department (ED) management within $72 \mathrm{~h}$ of the ED visit. Secondary endpoints include other measures of asthma severity and time to recovery within 7 days of the index visit. The study has $80 \%$ power for detecting a risk difference of $7.5 \%$ associated with each determinant from a baseline risk of $21 \%$, at an $\alpha$ of 0.05 .

Ethics and dissemination: Ethical approval has been obtained from all participating institutions. An impaired response to systemic steroids in certain subgroups will challenge the current standard of practice and call for the immediate search for better approaches. A potential host-environment interaction will broaden our understanding of corticosteroid responsiveness in children. Documentation of similar effectiveness of corticosteroids across determinants will provide the needed reassurance regarding current treatment recommendations.

\section{Strengths and limitations of this study}

- The proposed work will be the largest published cohort study exploring determinants of responsiveness to oral corticosteroids in children treated according to evidence-based acute asthma guidelines.

- The documentation of exposure using biomarkers to confirm parental reports enhances accuracy and precision of the determinants.

- The selection of a primary endpoint, that is, failure of emergency department (ED) management, the only clinical outcome that can be documented in all patients irrespective of age, carries enormous weight for modifying practice.

- A prospective cohort study is subject to potential biases inherent to this design. Loss to follow-ups will be quasi non-existent for the main and most secondary outcomes due to the short duration of follow-up in the emergency department. Confounding by indication will be minimised by the standardised severity-specific therapy.

- The inherent variability of admission and assessment of the Paediatric Respiratory Assessment Measure add noise to the data, which was taken into account in the sample size.

Results: Results will be disseminated at international conferences and manuscripts targeted at emergency physicians, paediatricians, geneticists and respirologists.

Trial registration number: This study is registered at Clinicaltrials.gov (NCT02013076).

\section{INTRODUCTION}

Asthma is the most common chronic disease in childhood. It affects over half a million Canadian children aged $4-11$ years. ${ }^{1}$ Of all 
respiratory illnesses, asthma is one of the most frequent paediatric diagnoses requiring hospital admission. ${ }^{1}$ The burden of illness is much higher in preschool-aged children, who account for over $50 \%$ of emergency department (ED) visits ${ }^{1-4}$ and who have three times the hospital admission rate of older children and adolescents. ${ }^{5}$ The difficulty in measuring asthma severity in young children has resulted in a dearth of comparative therapeutic evidence between preschoolers and older children. ${ }^{6-9}$

\section{Treatment of acute asthma}

National and international guidelines for the management of acute asthma recommend: (1) inhaled $\beta_{2}$-agonists for all patients; (2) systemic (usually oral) corticosteroids for those with moderate and severe asthma; and (3) repeated doses of inhaled $\beta_{2}$-agonists and anticholinergics for severe cases. ${ }^{6} 7910$ The latter two recommendations independently reduce admission rates by $25 \%$ in studies of predominantly school-aged children. ${ }^{11}{ }^{12}$ Several features must be noted. First, recommendations are severityspecific; patients with mild asthma do not appear to benefit from oral corticosteroids. ${ }^{11}{ }^{13}$ Second, the concept of the 'golden first hour of treatment' supports early and aggressive asthma management, as the risk of admission is reduced only when oral corticosteroids are administered $3-4 \mathrm{~h}$ prior to the decision to admit. Third, of all treatments administered in the ED, oral corticosteroids are by far the most effective for preventing admission. ${ }^{14}$ Fourth, there is no equally effective substitute for oral corticosteroids; promising contenders such as high-dose inhaled steroids, ${ }^{15}{ }^{16}$ intravenous antileukotrienes ${ }^{17}$ or magnesium sulfate ${ }^{18}$ have been shown to be inferior to oral corticosteroids and are used as an add-on therapy. Fifth, systemic corticosteroids are inexpensive generic drugs. Short treatment with oral corticosteroids is generally devoid of significant side effects, ${ }^{19}$ though rare cases of fatal or disseminated varicella have been reported. ${ }^{20}$ Sixth, while recommendations are relatively similar in young children, older children and adults, the evidence for the former is weaker due to the under-representation of preschool-aged children in relevant trials. ${ }^{11} 12$ While oral corticosteroids are the cornerstone of management of acute, moderate or severe asthma, ${ }^{6}$ several reports have recently shaken the belief that they are equally effective for all patients with asthma, showing that children with viral-induced wheezing $^{21}$ and smoking adults ${ }^{22}$ are corticosteroid-resistant. Indeed, in a large placebo-controlled randomised controlled trial of 700 children aged 10-60 months with mild-to-moderate viral-induced wheezing, oral corticosteroid was not superior to placebo for reducing the length of stay in hospital or improving the Pediatric Respiratory Assessment Measure (PRAM) clinical score, despite adequate study power. ${ }^{21}$ Critics have suggested that: (1) in most children, the disease may not have been asthma (documented in only $16 \%$ of patients) but rather the North American definition of bronchiolitis; (2) some patients (with mild asthma) may not have needed corticosteroids $^{23}$; (3) the prolonged stay in hospital did not seem to be supported by severity ${ }^{24}$ and (4) the dose of 1 (instead of 2) $\mathrm{mg} / \mathrm{kg}$ may have been insufficient. Yet, this study elicited major discomfort regarding acute asthma management in young children. ${ }^{24}$ In another adequately powered landmark trial, a 2-week treatment with prednisone showed a marked blunting of response in adult smokers, with an improvement in forced expiratory volume in $1 \mathrm{~s}\left(\mathrm{FEV}_{1}\right)$ of $237 \mathrm{~mL}(95 \%$ CI 43 to 431$)$ in never-smokers compared to no change or 47 ( -148 to 243) $\mathrm{mL}$ in current smokers. ${ }^{22}$ The question remains as to whether smoking adolescents and children with environmental tobacco smoke (ETS) respond as well as those not exposed. None of these aforementioned findings have been replicated, thus prompting us to review the potential determinants of responsiveness.

\section{Potential determinants of response \\ Disease diagnosis}

Children with bronchiolitis do not respond to oral corticosteroids, although a recent trial has demonstrated a significant response only in association with nebulised epinephrine. ${ }^{25-27}$ It is thus critical to distinguish asthma from bronchiolitis in young children. ${ }^{28}$ Bronchiolitis is clinically defined in North America as the first wheezing illness in a child $\leq 12$ months, with respiratory syncytial virus (RSV) as the most frequent pathogen. Asthma, defined as airway obstruction (cough, dyspnoea and wheezing) with hyper-reactivity and reversibility with bronchodilator or corticosteroids, begins early in life. ${ }^{29} 30$ While children and adults meeting these criteria can be diagnosed at the first episode, generally three wheezing episodes are required for children $\leq 12$ months to reduce the risk of misclassification with bronchiolitis. ${ }^{8} 31$ Heterogeneous groups of children with bronchiolitis and asthma may explain the poor response to oral corticosteroids in studies including infants and toddlers. ${ }^{21}{ }^{24}$ Thus, an operational definition of asthma, clinically applicable to children aged $1-17$ years, is needed to reasonably exclude bronchiolitis.

\section{Upper respiratory tract infections}

Upper respiratory tract infections (URTIs), usually viral in origin, are the most frequent $(60-80 \%)$ triggers of asthma exacerbation in children. ${ }^{32-34} \mathrm{RSV}$, parainfluenza virus and rhinovirus are frequently implicated in children under 2 years of age, while picornavirus, coronavirus and influenza are usually associated with asthma in older children. ${ }^{35-38}$ The incidence of viral-induced asthma peaks in September continues throughout the fall and winter. ${ }^{32}$ In adults with acute asthma, viral infection is associated with longer hospital admission ${ }^{39}$ and increased sputum neutrophils, suggesting a predominantly neutrophilic airway inflammation. ${ }^{39}$ In a study of children aged 3-36 months, those infected with rhinovirus showed fewer relapses when treated with oral prednisone compared to placebo, suggesting that rhinovirus did not impair responsiveness to steroids. ${ }^{40}$ In another 
placebo-controlled trial of 283 young children with wheezing, prednisolone did not significantly decrease the overall time to discharge; however, it reduced by half the length of stay in children infected with picornavirus and by fourfold that of children with enterovirus, suggesting that response may be organism dependent. ${ }^{41}$ Clearly, oral corticosteroids may not be as effective in patients with viral infections as in those without, perhaps due to neutrophilic airway inflammation, a condition associated with poor response to corticosteroids. Moreover, response may be organism specific, a hypothesis that requires careful documentation of aetiology.

\section{Exposure to tobacco smoke}

In addition to the aforementioned trial demonstrating no response to oral corticosteroids in asthmatic adult smokers, ${ }^{22}$ a blunted response to inhaled corticosteroids was also documented in adult smokers in two randomised controlled trials. ${ }^{42} 43$ While the mechanism behind the lack of response is not known, one can certainly point to smoking's direct toxicity, proinflammatory action or interference with the transcription of genes associated with corticosteroid response. ${ }^{22}$ Indeed, smoking has frequently been associated with airway neutrophilia. ${ }^{44}$ In paediatrics, exposure to tobacco smoke has been associated with a higher incidence of URTIs and prevalence of asthma, and a greater severity of exacerbations. ${ }^{45}$ However, the impact on the therapeutic response has not been documented in children, as asthma trials have not examined or failed to report subgroup analyses on ETS exposure or active smoking. Heavier ETS exposure in preschoolers who spend more time at home than school-aged children ${ }^{46} 47$ may explain a poorer response in young children. Objective documentation of smoking would also be important if possible, even before high school where many already smoke. ${ }^{48}$ Of particular concern is whether a blunted response to oral corticosteroids would be found in children exposed to tobacco smoke and adolescents with a short history of active smoking. With $25 \%$ of asthmatic children exposed to ETS and $25 \%$ of teenagers actively smoking, ${ }^{49-51}$ such an assessment appears critical.

Several reports highlight the need for objective measurement of nicotine exposure, because of parental underreporting of their child's exposure to ETS. ${ }^{46}{ }^{52}$ Cotinine, a nicotine metabolite with a half-life of $20 \mathrm{~h}$, is a widely accepted indicator of recent tobacco use and exposure. ${ }^{53}$ Serum cotinine requires blood sampling, a major deterrent for study participation in paediatrics. ${ }^{43}$ Good correlations exist between serum and either salivary $(\mathrm{r}=0.71)$ or urine $(r=0.69)$ cotinine measures ${ }^{53}$ With a $1: 10$ ratio of cotinine level between saliva and urine ${ }^{54}$ passive exposure may lead to saliva levels of $5-10 \mathrm{ng} / \mathrm{mL}^{55} 56$ and urine levels of $10-100 \mathrm{ng} / \mathrm{mL} .{ }^{45}$ However, as urine sampling in young children may not occur for several hours and is more complex to obtain in children not yet toilet-trained, saliva cotinine measured by the quantitative enzyme immunoassay kit is a well-validated, non-invasive solution that offers required precision with minimal volume and a detectable level of $0.05 \mathrm{ng} / \mathrm{mL}^{56} 57$

\section{Other determinants}

A number of other factors could possibly modulate the responsiveness to oral corticosteroids including, among others, gender, ${ }^{1}$ race, ${ }^{58}{ }^{59}$ perceived asthma phenotype (derived from age, common asthma triggers and interim symptoms), ${ }^{316061}$ inhaled corticosteroids, ${ }^{2} 7362$ allergens, the alleged trigger, ${ }^{63}$ and other environmental triggers, all of which can be documented clinically by questionnaire.

\section{Mechanistic pathways}

Two promising mechanistic pathways may explain the variations in the magnitude of response observed in clinical effectiveness, namely (1) gene polymorphisms that may reveal potential gene-environment interactions and (2) the type of airway inflammation.

\section{Gene polymorphisms}

There is increasing evidence that inherited genes are not a deterministic genotype, but rather a genotype that encodes a potential range of phenotypes that will develop in response to a variety of environments. ${ }^{64}$ Consequently, a minor polymorphism between individuals in genes that modulate response to corticosteroids may predispose some people to environmentally induced problems, such as smoke-induced or viral-induced asthma. ${ }^{65}{ }^{66}$ Two major groups of genes are of interest: (1) those affecting susceptibility to asthma and (2) those directly interfering with response to corticosteroids by coding for major components of the pathway involved in corticosteroid action (table 1). In the first group, we selected eight polymorphisms in seven genes that can be divided into those coding for xenobiotic metabolising enzymes and those coding for mediators of inflammation and immunity, specifically the ones demonstrated to affect lung function, disease severity and interaction with exposure to ETS. ${ }^{67}{ }^{68}$ We selected polymorphisms affecting gene function, top-ranking single-nucleotide polymorphisms (SNPs) in a number of associated studies. Transforming growth factor $\beta 1$ polymorphisms were found to correlate with disease severity ${ }^{69}$; CC16 polymorphisms play a role in the development and persistence of the asthma phenotype in childhood ${ }^{70}$; CD14 polymorphisms have been linked to pathogenesis of asthma and lung function in smokers. ${ }^{71}$ The ORMDL3 gene confers susceptibility to early-onset asthma, particularly through interaction with early life exposure to ETS $^{6772}$; GSTM1 and GSTP1 are involved in the metabolism of polycyclic aromatic hydrocarbon derivatives and reactive oxygen species ${ }^{73}$;4 ;STM1 null and GSTP1 genotypes have been associated with an increased risk of asthma $^{75}$ and rapid decline of lung function among smokers. ${ }^{76}$ The ADRB2 receptor gene was found to contribute to the occurrence of wheeze among children who were exposed to tobacco smoke in utero and in early child$\operatorname{hood}^{77}$ and was related to $\beta_{2}$-agonist response. ${ }^{68}{ }^{78}$ Among genes affecting the corticosteroid and inflammatory 
Table 1 Summary of the polymorphisms in subset of candidate genes of relevance for asthma phenotype and corticosteroids response

\begin{tabular}{|c|c|c|c|}
\hline Gene & & Location & Position/SNP annotation \\
\hline TGF- $\beta 11$ & Transforming growth factor $\beta$ & $\begin{array}{l}\text { Promoter } \\
\text { Coding }\end{array}$ & $\begin{array}{l}\text {-C-509T rs } 1800469 \\
\text { T869C rs } 1982073\end{array}$ \\
\hline CD141 & Monocyte differentiation antigen CD14 & Promoter & C-159T rs2569190 \\
\hline CC161 & Clara cell $16 \mathrm{kDa}$ secretory protein & 5'UTR & A38G rs3741240 \\
\hline ADRB21 & $\beta$-2-adrenergic receptor & Coding & Arg16Gly rs1042713 \\
\hline GSTM1* & Glutathione S transferase $\mathrm{M} 1$ & Gene deletion & GSTM1 null genotype \\
\hline GSTP1* & Glutathione S transferase $\mathrm{P} 1$ & Coding & Ile105Val rs1695 \\
\hline ORMDL3* $^{*}$ & Orm1-like protein 3 & Intronic & $\mathrm{A} / \mathrm{C}$ rs4795405 \\
\hline CRHR1† & Corticotropin-releasing hormone receptor 1 & Intronic & A/G rs242941 \\
\hline TBX21† & Tbox 21 & $\begin{array}{l}\text { Coding } \\
\text { Promoter }\end{array}$ & $\begin{array}{l}\text { H33Q rs2240017 } \\
\text { T-1514C rs17250932 } \\
\text { G-999A rs11650451 } \\
\text { T-1993C rs4794067 }\end{array}$ \\
\hline FCER2† & Fc fragment of IgE, low affinity II, receptor for (CD23) & Intronic & T2206C rs28364072 \\
\hline GLCCI1† & Glucocorticoid-induced transcript 1 & 5'UTR & $\mathrm{C} / \mathrm{T}$ rs37972 \\
\hline SERPINE1† & Plasminogen activator inhibitor-1, & Promoter & -675 4G/5G rs1799889 \\
\hline STIP1† & Stress-induced phosphoprotein & & $\mathrm{G} / \mathrm{T}$ rs4980524 \\
\hline STIP1† & Stress-induced phosphoprotein & & rs2236647 \\
\hline
\end{tabular}

pathways, we selected genes (CHRH1, TBX21, FCER2, GLCC1, STIP1 and SERPINE1) that were shown to correlate with response to corticosteroids in patients with asthma; the finding for some of them was replicated in several cohorts. ${ }^{79-84}$ All selected polymorphisms with the gene name, position and corresponding reference are summarised in table 1. Genotyping is essential to link the observed corticosteroid response to genotype and to evaluate the potential host-environment interaction.

\section{Airway inflammation}

Induced sputum is a valid, reproducible and non-invasive method of assessing the magnitude and pattern of airway inflammation in adults and children. ${ }^{85}$ Sputum cell counts and differentials (ie, eosinophils and neutrophils) determine the inflammatory phenotype; analysis of supernatants for eosinophil cationic protein (ECP), interleukin-8 (IL-8) and myeloperoxidase provides measures of cellular activation. Sputum eosinophils and ECP increase with exposure to allergens and decrease with corticosteroid treatment. ${ }^{86}$ A higher proportion of neutrophils is associated with smoking ${ }^{22} 4487$ and with viral infection. ${ }^{39} 88$ The non-eosinophilic inflammatory phenotype in adults has been associated with poor response to corticosteroids. ${ }^{89} 90$ Markers of this phenotype include an increased proportion of neutrophils, IL-8 and myeloperoxidase, all of which are easily quantifiable. ${ }^{91}{ }^{92}$ Contrary to adult findings and criteria, three distinct inflammatory cell patterns have been reported during paediatric exacerbations: non-eosinophilic $(<2.5 \%$ eosinophils $)$ in $22 \%$, eosinophilic $(\geq 2.5 \%$ eosinophils) in $43 \%$ and combined eosinophilic/neutrophilic $(\geq 2.5 \%$ eosinophils and $>54 \%$ neutrophils) in $35 \%$, with paucigranular inflammation not described in acute paediatric asthma. ${ }^{62}$ Combined eosinophilic/neutrophilic exacerbations show more mast cells and higher sputum ECP levels than eosinophilic exacerbations. There is increasing evidence that eosinophilic asthma is more responsive to corticosteroids than non-eosinophilic asthma; a promising mechanistic pathway to explore. ${ }^{93} 94$

Expired nitric oxide (eNO) is increasingly recognised as a non-invasive marker of airway inflammation, particularly in atopic asthma, ${ }^{95} 96$ and correlates strongly with the percentage of airway eosinophils $(\mathrm{r}=0.78)$ and ECP $(\mathrm{r}=0.53)$ in children with asthma. ${ }^{97}$ Although the understanding about the link between NO and airway inflammation remains incomplete, airway epithelial cells activated by inflammatory cytokines produce an increased amount of eNO due to the expression of inducible NO synthase. ${ }^{98}$ eNO is elevated in untreated asthma ${ }^{99}$ and improves with asthma therapy. ${ }^{100} 101$ Of interest, eNO correlates with other markers of eosinophilic inflammation, including sputum eosinophils. ${ }^{102} 103$ Thus, eNO appears to reflect the magnitude of eosinophilic airway inflammatory and may serve as a promising biomarker of eosinophilic inflammation in children too young or unable to cooperate with induced sputum sampling. ${ }^{104}$ As it can be measured in preschool-aged using an offline technique ${ }^{105} 106$ and in older children using commercially available instruments, ${ }^{107} 108$ it could serve as a biomarker of subsequent response to corticosteroids if indeed the type of airway inflammation modulates response.

\section{Selection of outcomes}

Healthcare service utilisation

The need for hospital admission is a powerful marker of therapy failure, likely to alter physicians' practice and 
influence decision makers as hospital costs alone account for $43 \%$ of total asthma costs. ${ }^{109}$ Although subject to practice variation, a physician's decision to admit is usually based on an unsatisfactory response to bronchodilators and systemic corticosteroids in the ED, indicating severe asthma or poor response to corticosteroids. ${ }^{22}$ Admission may be affected by other reasons such as parental anxiety, distance or fatigue and, of course, availability of ED and hospital beds. ${ }^{50}$ Adding a cut-off length of ED stay, above which a patient is considered admitted, limits the impact of external factors (bed availabilities) which may vary widely within and between institutions. Moreover, incorporating return visits resulting in admission provides an additional measure of failure of ED treatment by adding a measure of the decision appropriateness. Time to meet severity criteria for discharge (PRAM <4) and length of active treatment are two additional measures of interest that are less influenced by factors other than severity.

\section{Indicators of airway dysfunction}

Accurate and objective assessment of the severity of airway obstruction is clearly the biggest challenge in acute paediatric asthma research. Standard lung function tests, such as spirometry, require a forced expiratory manoeuvre that is extremely difficult and unreliable for preschool-aged children because of poor coordination; it is not obtainable in 35-50\% of acutely ill school-aged children because of illness severity and/or poor familiarity with technique. ${ }^{110-}$ 112 About three quarters of asthmatic children cannot perform standard lung function tests in the ED setting. ${ }^{13}$ In contrast, respiratory resistance (Rrs) by forced oscillation is an effort-independent measure that can be obtained in untrained, acutely ill children aged $\geq 3$ years ${ }^{110}$ We and others have demonstrated the reproducibility and sensitivity to change $\operatorname{Rrs}^{114}$ and established reference values for Canadian children. ${ }^{115} 116$ Thus, the measure of Rrs can serve as a precise and reliable index of severity and response in acutely ill children, although still missing very young or uncooperative preschoolers and as such cannot serve as the main outcome.

Clinical scores appear to be a reasonable alternative to lung function testing as they can be used in children of all ages. Although many clinical scores have been designed, only two have been validated for use in both preschool-aged and school-aged children. ${ }^{112} 117$ The PRAM is the only score developed and validated against a concurrent measure of lung function in children aged $3-6$ years, ${ }^{117}$ and subsequently validated in children aged $1-17$ years. ${ }^{23}$ It is a discriminative and responsive tool, with a change in scores $\geq 3$ indicating clinical importance. ${ }^{23} 117$ The inter-rater reliability is consistently above $70 \%{ }^{23}$ The 12-point PRAM, rating five weighted items (oxygen saturation, suprasternal retractions, scalene muscle contraction, air entry and wheezing), has been used in landmark clinical trials. ${ }^{21}$ It can be used to assess severity at baseline (mild: PRAM 0-3; moderate: PRAM 4-7; severe: PRAM 8-12), improvement with treatment depicted as the area under the curve, need for admission (PRAM $\geq 4,4 \mathrm{~h}$ after the oral corticosteroids) and time until ready for discharge (delay until PRAM $<4) .{ }^{23}$

\section{Indicators of recovery following discharge}

Among children discharged home, the time to complete recovery will vary widely between individuals. Although symptom scores are frequently used in clinical trials, only four have been specifically developed for use in children. ${ }^{6971} 71$ The Asthma flare-up diary for young children (formerly the Pediatric Asthma Diary) is the only one validated to detect day-to-day change in the functional status of preschool-aged children following an acute care visit ${ }^{118}$; it is highly sensitive to detect group differences in intensity and duration of symptoms in randomised controlled trials; however, its performance in school-aged children has not been explored. ${ }^{119}$ Another diary has been validated for detecting change in school-aged children but not in the context of acutely ill children. ${ }^{120}$ Use of $\beta_{2}$-agonists is an additional marker for the duration and intensity of symptoms, as greater use of rescue relievers is expected to occur in children with more symptoms. ${ }^{119}$ Finally, the impact of the disease on the quality of life of the patient or the caregivers is a recognised, sensitive and unique marker of the burden of disease on the patient or family. ${ }^{121}$ Several well-validated asthma-specific quality of life instruments are available for adults ${ }^{122}$ and school-aged children with stable asthma. ${ }^{123}$ To our knowledge, only one instrument, entitled 'Effects of a child's asthma flare-up on parents', is available for measuring the burden of disease on parents of preschool-aged children following an asthma exacerbation; we have developed the instrument using Kirshner and Guyatt's ${ }^{124}$ approach for developing health instruments, validated it in a randomised controlled trial $^{119}$ and received two copyrights (French version: \#1019528 English version: \#1019529 (manuscript in preparation).

\section{Hypothesis}

In children presenting with moderate or severe asthma to the ED:

1. Preschool age, specific viral triggers and exposure to tobacco smoke are independently associated with increased risk of failure of ED management (risk difference $(\mathrm{RD}) \geq 7.5 \%$ ).

2. Specific genetic polymorphisms alone or in association with environmental factors are associated with higher risk of admission.

3. An eosinophilic pattern of airway inflammation (ie, percentage of eosinophils on induced sputum and/ or baseline eNO) is associated with greater clinical improvement as measured by the PRAM area under the curve over $4 \mathrm{~h}$ (nested cohort).

\section{OBJECTIVES}

The main objective was to identify and quantify clinically available factors (eg, age, specific viral trigger and ETS) associated with failure of ED management and other 
markers of clinical response to oral corticosteroids in preschool-aged and school-aged children presenting to the ED with moderate or severe asthma.

\section{Secondary objectives}

1. Examine the association between specific genetic polymorphisms (including potential host-environment interactions) and markers of response.

2. Determine whether the type of airway inflammation (ie, eosinophilic and eNO) is associated with the magnitude of response to corticosteroids and which host or episode characteristics are associated with a specific type of inflammation.

\section{METHODS}

Design

The study design is a multicentre prospective cohort study with a standard intervention involving 1008 children aged 1-17 years of age presenting with acute asthma to one of the five participating Canadian paediatric EDs. The study includes a nested cohort study of children who presented at selected centres and who could cooperate with eNO measurements (about 200) or induced sputum (about 60 children aged $\geq 8$ years) to explore the pattern of airway inflammation.

\section{Subjects}

Participants will be eligible if they: (1) are aged 1-17 years; (2) have asthma, defined as: (i) prior diagnosis of asthma made by a physician; (ii) prior documented episode of acute cough, wheezing and/or dyspnoea with significant response to inhaled $\beta_{2}$-agonists or to oral corticosteroids; (iii) in a child aged $<2$ years, three or more episodes of cough, wheezing and/or dyspnoea, including the index visit or (iv) previous lung function tests showing significant reversibility postbronchodilation $\left(\geq 12 \% \mathrm{FEV}_{1} \text { or } \geq 25 \% \mathrm{Rrs} \text { at } 4-8 \mathrm{~Hz}\right)^{117}$ or a positive provocation test $\left(\mathrm{PC}_{20} \leq 8 \mathrm{mg} / \mathrm{mL}\right.$ or provocation dose (to increase $\mathrm{Rrs}$ by $50 \%$ or more $\left(\mathrm{PD}_{50}\right) \leq 8 \mathrm{mg} / \mathrm{mL}$ ), in keeping with the American Thoracic Society and European Respiratory Society criteria ${ }^{125} 126$; (3) present with an acute episode of cough, wheezing and/or dyspnoea; (4) have moderate-to-severe airway obstruction, defined as a PRAM score $>3$ at baseline; (5) have a good understanding of English or French and (6) are accompanied by parents or legal guardians.

Patients will be excluded if they present: (1) with another chronic respiratory condition (such as bronchopulmonary dysplasia or cystic fibrosis); (2) with a reasonable suspicion of bronchiolitis or foreign body aspiration; (3) a history of hypersensitivity to salbutamol, ipratropium bromide or oral prednisolone; (4) a relative or absolute contraindication to receiving oral corticosteroids such as recent exposure to varicella or live vaccine in a susceptible child or (5) with confirmed or suspected pregnancy status. As some inclusion and exclusion criteria may become evident during or after the ED stay (ie, pneumonia), a central adjudicating committee comprising a paediatrician/ED physician and respirologist will review the eligibility criteria of children who, after enrolment, appear to be ineligible due to the failure to meet one or more inclusion or exclusion criteria and who did not receive or tolerate oral corticosteroids as recommended in the protocol. The main trigger for identifying these children will be the ED physician's low degree of confidence that this child had asthma, suspicion that he/she may have bronchiolitis and the suspicion that he/she did not retain the oral corticosteroids. In this case, the relevant case report forms, relevant anonymised laboratory testing (ie, imaging, microbiology, virology and haematology) and relevant anonymised medical chart sections will be reviewed by the adjudicating committee. The adjudicating committee will be central, although we are not ruling out the possibility of creating local committees at each site, depending on the volume of cases to review. In such a case, the site would be added as a covariate in the analysis. Disagreement will be resolved by consensus or the assistance of a third observer. The proportion of excluded children, assumed to be around $10 \%$, will be monitored and reported.

\section{Standardised acute treatment protocol}

As per the evidence-based paediatric national ${ }^{127}$ and international guidelines, ${ }^{9}$ children will be treated according to a standardised severity-specific protocol (table 1). All children will receive $2 \mathrm{mg} / \mathrm{kg}$ (maximum $50 \mathrm{mg}$ ) of oral prednisolone (or prednisone) within 60 min of triage, along with inhaled salbutamol with or without inhaled ipratropium bromide as per severity strata. Discharge medications will include a 5-day course of oral prednisolone at a dose of $1 \mathrm{mg} / \mathrm{kg} /$ day and inhaled $\beta_{2}$-agonists as needed. Cointerventions, such as add-on therapy with magnesium sulfate in the ED or inhaled corticosteroids at discharge, will be permitted and recorded. Comorbidities (eg, pneumonia, sinusitis, allergic rhinitis, etc) and adverse health events will be documented.

\section{Measurements of effectiveness}

The primary outcome, serving as a proxy for suboptimal response, is the failure of ED management defined as a hospital admission for asthma (as primary or secondary diagnosis if the primary diagnosis is a complication or comorbidity of asthma) or ED stay for asthma (with active treatment) of $\geq 8 \mathrm{~h}$ after intake of oral corticosteroids or a return visit within 72 hours meeting either of the two previous criteria (admission or length of active treatment $\geq 8$ hours). The $8 \mathrm{~h}$ time constraint was included to account for extraneous factors affecting admissions, such as variation in bed availabilities while the child remains under treatment on site.

Secondary measures of effectiveness in the ED include: (1) meeting the severity criteria for admission, that is, a PRAM score $\geq 4$ within $4 \mathrm{~h}$ of corticosteroid administration (to account for other reasons for hospital 
admission); (2) the PRAM profile in the ED, measured hourly from baseline and every hour until disposition (or until $4 \mathrm{~h}$ after intake of oral corticosteroids, whichever occurs first) and reported as the area under the curve; (3) time to PRAM $\leq 3$, that is, meeting the criteria for discharge; (4) length of active treatment defined as duration between the first and last salbutamol inhalation. Finally, to allow more objective and precise quantification of response in a nested cohort (CHU Ste-Justine), (5) change in Rrs between baseline and disposition will be documented on the MasterScreen Impulse Oscillometry (Cardinal Health Canada, Montreal, Canada) using previously described standardised techniques ${ }^{110} 114 \quad 126$ in cooperative children aged $\geq 3$ years, (6) change in eNO between baseline and disposition will be documented on a chemiluminescence NO analyser in cooperative children aged $\geq 4$ years and (7) hospital admission for asthma (as primary or secondary diagnosis) within $72 \mathrm{~h}$ or an active ED stay of $\geq 8 \mathrm{~h}$ after intake of oral corticosteroids.

Secondary measures of resolution of exacerbation measured after discharge will be documented over the next 10 days in all patients: (8) unscheduled visits for asthma as reported by parents and confirmed by medical charts; (9) cumulative symptom score and duration of symptoms measured daily on the validated Asthma flare-up diary for young children (formerly named the Paediatric Asthma Diary) ${ }^{118}$; (10) parent quality of life measured on the 'Effect of a child's asthma flare-up on parents' and (11) the cumulative number of puffs and duration of use of rescue $\beta_{2}$-agonists as recorded on the Asthma flare-up diary for young children.

\section{Potential determinants}

\section{Sociodemographic variables}

Basic characteristics will be documented, including age, gender, neighbourhood financial income derived from six-digit postal codes from both parents (if separated), medical insurance (private or public) and ethnicity as reported by the parents and classified as per the latest Canadian Census questionnaire.

\section{Phenotype and morbidity}

Children's asthma phenotype will be documented as per the latest international recommendations (ie, viral induced, exercise induced, allergen induced and multiple trigger). ${ }^{31}$ Prior morbidity (admissions, ED visits and rescue oral corticosteroids), asthma control using the Asthma Quiz for Kidz, ${ }^{128}$ reported use of daily controller medications, environmental factors (eg, dust, animals and pollen) and perceived trigger of the exacerbation will be documented. Prior allergy test results, serum IgE (specific) will be obtained (with permission) as well as pollen counts in the area.

\section{Viral trigger}

Acknowledging viruses as the major trigger, all children will be tested for respiratory viruses. All children will have a nasopharyngeal aspirate or nasopharyngeal swab (Flocked swab, Copan Diagnostics, California, USA) performed. The aspirate or swab will be put in $3 \mathrm{~mL}$ of viral transport media (UTM, Copan Diagnostics, California, USA) and split in half on site. The first half will be tested using routine methods in each site if clinically required and the other half will be frozen at $-80^{\circ} \mathrm{C}$ for molecular diagnosis. The frozen samples will be processed using the validated automated microarray detection, ${ }^{129}$ which tests for 23 common respiratory viruses, including the novel influenza A/H1N1/Mexico.

Passive exposure to tobacco smoke will be quantified by a questionnaire specifically enquiring about current smoking and the amount of smoking by household members, cumulative smoke exposure in pack-years since birth and in utero exposure, using validated questions. ${ }^{51}{ }^{130}$ Active smoking will be assessed by asking school-aged children aged 10 years and older, while alone, if they smoked in the past 7 days, using standardised questions used by the Quebec Institute of Statistics. ${ }^{131}$ A quantitative cotinine by quantitative enzyme immunoassay kit (Salimetrics, Pennsylvania, USA) will be performed on saliva sampled using three Sorbettes (a wand with a small sponge) according to a previously described protocol. ${ }^{56} 57$

Several other factors will be considered, including an assumed trigger. In the absence of valid biomarkers of causal relationship to the exacerbation, the alleged trigger (allergic or other) based on the parental report, physician perception, prior documented sensitisation (skin tests or specific IgE), pollen, particles, ozone (and other) levels in the child's living area will serve to infer a trigger.

\section{Mechanistic pathway \\ Genetic profile}

Patients' DNA will be extracted from saliva expectoration or collected on Sorbettes designed for young children, with only a small amount (1-2 mL) needed for DNA analysis. After amplification by PCR, key polymorphisms ${ }^{132} 133$ will be determined by high throughput genotyping technology (Sequenom platform) for custom SNP panels.

$e N O$ will be measured on a chemiluminescence analyser (the Niox Flex or the portable Niox Mino from Aerocrine, New Providence, New Jersey, USA or Sievers from GE Analytic Instrument, Boulder, Colorado, USA), using standardised techniques ${ }^{98}$ in cooperative children aged $\geq 4$ years; the measurements will be taken before corticosteroids and at $4 \mathrm{~h}$ or disposition, whichever occurs first. In children unable to cooperate with these techniques, the eNO will also be measured, using the single breath manoeuvre, in an inert balloon (offline technique) and then analysed on the chemiluminescence analyser. ${ }^{105} 106$

\section{Induced sputum}

After the initial salbutamol inhalation, children aged $\geq 7$ years will be asked to expectorate spontaneously or, if 
unsuccessful, receive a nebulisation of $0.9 \%$ saline solution over $7-10 \mathrm{~min}$ at $5 \mathrm{~L} / \mathrm{min}$ with oxygen. With this technique, a $70 \%$ success rate was obtained among acutely ill school-aged asthmatic children. ${ }^{134-136}$ Throughout the induction, lung function tests using Rrs will be documented to ensure that the coughing effort does not induce bronchospasm. ${ }^{134}$ Sputum will be processed according to standard techniques within $8 \mathrm{~h}$. Briefly, sputum will be separated from the saliva and dispersed using dithiothreitol. The dispersed suspension is then centrifuged and filtered; cytospin slides will be prepared on site by a trained medical technologist, and the supernatant frozen at $-70^{\circ} \mathrm{C}$ for subsequent quantification of inflammatory mediators. Differential cell counts and inflammatory mediators will each be analysed by an independent laboratory, blinded to exposure and outcome.

\section{Procedures}

Within each institution, potentially eligible patients aged $1-17$ years will be identified on arrival in the ED. As per standard practice in each of the participating hospitals, all children will be triaged and scored on the PRAM at or shortly after triage. The first inhalation of salbutamol and, for severe exacerbations, ipratropium bromide will be administered (figure 1). Using a two-step informed consent, parents will first give their authorisation for their child to receive standardised severity-specific treatment and, at the CHU Ste-Justine, lung function testing and induced sputum in cooperative children. Parents will then receive a detailed explanation of the study and be offered study participation. Participants will receive the treatment and measures detailed in figure 1, with key measurements obtained prior to corticosteroids.

\section{Statistical analyses}

Standard summary statistics (N, mean, SD, median, minimum and maximum for continuous variables; $\mathrm{N}$ and proportion for categorical variables) will be computed for all variables for the whole cohort and by institutions. Two-sided 95\% CIs will be presented as necessary. For the primary endpoint, failure of ED management and other dichotomous outcomes, bivariate and multivariate logistic regression models will be used to examine the association with each potential determinant and to adjust for site, baseline severity and other relevant covariates of interest. ORs will be estimated and presented with twosided 95\% CIs. Continuous outcomes, such as the area under the curve for repeated PRAM measures, daily Asthma flare-up diary for young children or intensity of both $\beta_{2}$-agonist use and symptom scores after discharge, will be analysed using linear regression models. Transformation of variables will be performed if necessary to account for non-normality of the residuals.

With regard to pharmacogenomics, we will compare the frequency of SNPs between patients with versus without failure of ED management using Fisher's exact tests and examine the strength of the association with failure of ED management with bivariate and multivariate logistic regression. Genotypes will be considered as variables with two (dominant or recessive models) or three (additive model) categories. The choice of the model is determined by the functionality of selected polymorphisms and previous reports. Bonferroni correction will be used to adjust for multiple testing ( $\mathrm{p}=0.005$, adjusted for 10 independent genes investigated). Host-environment interaction will be examined by adding other covariates of interest to the genotype model. For example, to investigate genetic heterogeneity according to early-life exposure to ETS, we will introduce markers of tobacco smoke exposure status.

With regard to examining eosinophilic inflammation as a marker of responsiveness, the area of the curve of serial PRAM measurements and time to PRAM $<4$ will serve as outcomes. Linear regression will be used to examine the bivariate and multivariate relationships between sputum eosinophils counts, patterns of inflammation (eosinophilic, non-eosinophilic and mixed) and baseline eNO with the PRAM profile (area under the curve); the standard survival curve will explore the difference in time to meet criteria for discharge, censored at 4 h. ${ }^{137}$ All models will be checked using appropriate regression diagnostics. Results will be reported as significant when $\mathrm{p}<0.05$.

\section{Sample size}

Sample size was estimated in two steps using hospital admission as the dependent variable in a multivariate logistic regression model. Pilot data were extracted from two large recent chart audits ${ }^{14}{ }^{138}$ totalling 1628 children presenting with acute asthma to the ED (in which age, gender, baseline PRAM, timing of oral corticosteroid intake and admission were documented) and two recently completed trials ${ }^{119} 139$ totalling 518 children, in whom tobacco exposure was also ascertained by questionnaire; we then focused only on children meeting our current eligibility criteria (age, baseline PRAM and corticosteroids within an hour of arrival). Based on the literature, we assumed the prevalence of viral pathogen varied between $60 \%$ and $80 \% .{ }^{140} 141$ The baseline risk of admission was $41 \%$; after recruitment of the initial 320 patients, the observed overall risk of admission was substantially lower at $16 \%$, which substantially reduced the effective sample size from 1200 to 800 . First, using the Wald test (based on the prevalence of factors and the risk of admission in unexposed children), we calculated the sample size required to detect an RD of admission of $7.5 \%$, taking each determinant in turn as the independent variable in a bivariate logistic regression; we used $95 \%$ CIs for each estimate obtained from pilot data to examine the impact on power. ${ }^{142}$ Then, using the method proposed by Hsieh et $a l,{ }^{143}$ we calculated the inflation factor to adjust the total sample size, based on the observed correlation between key determinants 


\begin{tabular}{|c|c|c|c|}
\hline $\begin{array}{c}\text { Pediatric Respiratory } \\
\text { Assessment Measure } \\
\text { (PRAM) } \\
\end{array}$ & Oral corticosteroids $\S$ & $\begin{array}{c}\text { Inhaled salbutamol }^{\dagger} \\
100 \mathrm{mcg} / \text { puff }\end{array}$ & $\begin{array}{c}\text { Inhaled ipratropium bromide } \\
21 \mathrm{mcg} / \text { puff }\end{array}$ \\
\hline \multicolumn{4}{|c|}{ Within initial $60 \pm 15$ minutes of triage } \\
\hline $\begin{array}{c}\text { MODERATE ASTHMA } \\
\text { PRAM 4-7 }\end{array}$ & $\begin{array}{l}\text { Drug: Prednisone or } \\
\text { prednisolone } 2 \mathrm{mg} / \mathrm{kg}, \max : 50 \\
\mathrm{mg*}\end{array}$ & $\begin{array}{l}\text { Delivery device: } \mathrm{MDI} \text { (or nebulizer) } \\
\text { Dose: } 0.3 \mathrm{puffs} / \mathrm{kg} \text { of } 100 \mathrm{ug} / \mathrm{puff} \text { (max } \\
10 \text { puffs) (or } 0.3 \mathrm{~mL} / \mathrm{kg} \text { of } 5 \% \\
\text { salbutamol solution) } \\
\text { Frequency: } \mathrm{q} 20 \text { to } 30 \text { minutes }\end{array}$ & Not recommended \\
\hline $\begin{array}{c}\text { SEVERE ASTHMA } \\
\text { PRAM }>7\end{array}$ & As above & $\begin{array}{l}\text { MDI and dose }: \text { as above } \\
\text { Frequency: } q 20 \text { minutes }\end{array}$ & $\begin{array}{l}\begin{array}{l}\text { Delivery device: MDI (or } \\
\text { nebulizer) }\end{array} \\
\text { Dose: } 3 \text { puffs (or } 250 \mathrm{ug} \text { ) } \\
\text { Frequency: } \mathrm{q} 20 \mathrm{~min} \\
\end{array}$ \\
\hline \multicolumn{4}{|c|}{ Beyond initial 60 minutes until discharge } \\
\hline PRAM 4-7 & - & $\begin{array}{c}\text { As above } \\
\text { q } 30-60 \text { minutes }\end{array}$ & \\
\hline PRAM $>7$ & - & $\begin{array}{c}\text { As above } \\
\text { q } 30 \text { to } 60 \text { minutes }\end{array}$ & \\
\hline \multicolumn{4}{|c|}{ At discharge } \\
\hline & \begin{tabular}{|l|} 
Prednisone or prednisolone \\
$1 \mathrm{mg} / \mathrm{kg} \mathrm{x} 4$ days, $\max : 50 \mathrm{mg} *$
\end{tabular} & $2-4$ puffs q 4 to 6 hours as needed & \\
\hline
\end{tabular}

* Administered as prednisone 5 (or $50 \mathrm{mg}$ ) or prednisolone $1 \mathrm{mg} / \mathrm{mL}$ solution

T Administered via age-appropriate valve spacer

$\S$ If patient vomits, use oral dexamethasone $0.15-0.30 \mathrm{mg} / \mathrm{kg}$ per dose of parenteral solution ( $\max 10 \mathrm{mg}$ )

If impending respiratory failure, use methylprednisolone $1-2 \mathrm{mg} / \mathrm{kg}$ ( $\max 80 \mathrm{mg}$ ) or hydrocortisone $4-8 \mathrm{mg} / \mathrm{kg}$ ( $\mathrm{max} 400 \mathrm{mg}$ )

Figure 1 The treatment protocol is stratified on the severity of asthma exacerbation, that is, moderate or severe, as measured by the validated Pediatric Respiratory Assessment Measure (PRAM). Categories of medications are listed in the three columns. The three horizontal panels describe therapy administered in the first 60 minutes (top panel); after the initial 60 minutes (middle panel); and on discharge (bottom panel).

(age, gender and tobacco exposure, and baseline severity). As the observed correlation between determinants and severity and any pair of determinants was negligible ( $\beta$ coefficients $<0.03$ ), there was no need to inflate the sample size. At an $\alpha$ of 0.05 , a sample of 800 children had $80 \%$ power to detect an RD of admission of $\geq 7.5 \%$ for all key determinants. We targeted the RD of $7.5 \%$, because it was considered in a survey of researchers of the Pediatric Emergency Research in Canada (PERC) network as a clinically meaningful effect size that would support a practice change. After documenting a $1 \%$ loss after enrolment (from $10 \%$ originally estimated) and $20 \%$ missing key samples (viral or cotinine), our target recruitment sample is 1008 to obtain an effective sample of 800 children. Acknowledging that the majority of selected polymorphisms have a minor allele frequency of at least $30 \%$ and using an $\alpha$ of 0.005 (with a Bonferroni correction for 14 polymorphisms), 1008 children will provide $80 \%$ power to detect an OR of 1.5 between each polymorphism and admission. Finally, of the expected 400 children recruited at the University Health Centre Sainte-Justine, we estimated that 200 children would cooperate with eNO measurements and 60 with induced sputum. These sample sizes should be adequate to detect a correlation coefficient as low as $0.2-0.35$, respectively, with the area under the curve of the PRAM score during the ED with $80 \%$ power and a two-sided $0.05 \alpha$.

\section{ETHICS AND DISSEMINATION}

This study poses little risk to participants, as all children will receive state-of-the-art asthma management with oral corticosteroids, an approach associated with minimal side effects. ${ }^{19} 144145$ Children will be assessed for potential contraindication to corticosteroids prior to enrolment. Using a two-step informed consent, parents will first give their authorisation for their child to receive the severityspecific asthma protocol and, at specific centres, lung function testing and induced sputum in cooperative children; then they will consent to the full study including sampling for cotinine, DNA and viruses. All parents will sign an informed consent form authorising the DNA analysis for the specified research purpose as well as future analyses (including biobanking of DNA in anonymised fashion), provided these are approved by the institutional ethics boards. Assent will be obtained from children aged $\geq 7$ years. The collection of saliva by expectoration or sponge is painless and well tolerated by children. Nasopharyngeal aspiration or swab for viral diagnosis is a commonly used procedure in the ED setting; it is rapid and associated with little discomfort. The performance of Rrs and eNO is non-invasive and devoid of serious side effects. Sputum induction with $0.9 \%$ saline and salbutamol pretreatment is a safe procedure in the acute care setting. ${ }^{134-136}$ Data safety is maximised through: restricted physical access to computers and electronically protected servers (firewall, restricted password-protected 
access, daily back-up and storage in 2 different locations). Confidentiality is also a part of standard operating procedures; a unique research code will be assigned to each patient. All research data and specimens will be kept in locked rooms with restricted access at each site, the coordination centre and the site of analysis. The protocol, consent form and any amendments are subject to the ethics review board approval of each institution. Each investigator will adhere to the principles of the Declaration of Helsinki. All serious adverse effects will be promptly reported.

This study will provide needed answers as to whether oral corticosteroids are less effective for preventing hospital admission in subgroups of children and, if so, which clinically available characteristics could be used to identify patients at risk of poorer response. An impaired response to systemic steroids in certain subgroups, resulting in a higher rate of failure of ED management and/or impaired recovery, would challenge the current standard of practice and call for an immediate search for better approaches. Given the high prevalence of suspected factors (young age $(60 \%)$, viral infection $(60-80 \%)$, ETS $(20-30 \%))$, the potential impact of poor response on the rate of failure of ED management is sizeable. The exploration of potential hostenvironment interactions will broaden our understanding of corticosteroid responsiveness in children and enable us to focus on relevant alternative/supplemental strategies to adequately manage these patients. Documentation of the similar effectiveness of systemic corticosteroids across determinants will provide the needed reassurance as to the value of national recommendations for the treatment of all children with acute asthma.

Results will be disseminated at international conferences targeting emergency physicians, paediatricians, geneticists and respirologists. Four manuscripts are envisioned: one pertaining to the identification of main determinants of the risk of failure of ED management within $72 \mathrm{~h}$ of the dose of oral corticosteroids (general medical journal); one pertaining to the validation of perceived triggers and clinical predictors of response to therapy during the index exacerbation (emergency medicine journal); one pertaining to the genetic polymorphisms associated with non-response to oral corticosteroids (respirology journal); and one pertaining to the gene-environment interaction modulating the response to corticosteroids in children (paediatric journal).

\footnotetext{
Author affiliations

${ }^{1}$ Department of Pediatrics, University of Montreal, Montreal, Quebec, Canada

${ }^{2}$ Department of Social and Preventive Medicine, University of Montreal,

Montreal, Quebec, Canada

${ }^{3}$ Research Centre, Sainte-Justine University Health Centre, Montreal, Quebec, Canada

${ }^{4}$ Children's Hospital of Eastern Ontario, University of Ottawa, Ottawa, Ontario, Canada

${ }^{5}$ Montreal Children's Hospital, McGill University Health Center, Montreal,

Quebec, Canada
}

${ }^{6}$ Children's Hospital, London Health Sciences Center, London, Ontario,

Canada

${ }^{7}$ Research Institute, McGill University Health Center, Montreal, Quebec, Canada

${ }^{8}$ Centre Hospitalier de I'Université Laval, Quebec, Quebec, Canada

${ }^{9}$ Sacré-Coeur Hospital of Montreal, University of Montreal, Montreal, Quebec, Canada

${ }^{10}$ Montreal Heart Institute, University of Montreal, Montreal, Quebec, Canada

Contributors FMD conceptualised the research design, wrote the research protocol, secured the funding and coordinating the project team. MCG was responsible for the sample size calculation and statistical methods. RZ, JG, $\mathrm{DC}, \mathrm{NP}, \mathrm{SL}, \mathrm{CQ}, \mathrm{MK}, \mathrm{CG}$ and $\mathrm{CL}$ provided feedback to refine the research methodology and contributed to the implementation of the study. All authors read and approved the final version.

Funding This project is funded by a grant awarded through a peer-review process by the Canadian Institutes of Health Research (grant number 102547).

Competing interests None.

Ethics approval CHU Sainte-Justine Research Ethics Board (approval number 3127).

Provenance and peer review Not commissioned; peer reviewed for ethical and funding approval prior to submission.

Open Access This is an Open Access article distributed in accordance with the Creative Commons Attribution Non Commercial (CC BY-NC 3.0) license, which permits others to distribute, remix, adapt, build upon this work noncommercially, and license their derivative works on different terms, provided the original work is properly cited and the use is non-commercial. See: http:// creativecommons.org/licenses/by-nc/3.0/

\section{REFERENCES}

1. Public Health Agency of Canada (PHAC). Life and breath: respiratory disease in Canada. 11-12-2007. Ottawa: Public Health Agency of Canada (PHAC). Measuring up: a health surveillance update on Canadian children and youth. 10 Jun 2008.

2. Canny GJ, Reisman J, Healy R, et al. Acute asthma: observations regarding the management of a pediatric emergency room. Pediatrics 1989;83:507-12.

3. Schaubel D, Johansen $\mathrm{H}$, Mao $\mathrm{Y}$, et al. Risk of preschool asthma: incidence, hospitalization, recurrence, and readmission probability. $J$ Asthma 1996;33:97-103.

4. To T, Dick P, Feldman W, et al. A cohort study on childhood asthma admissions and readmissions. Pediatrics 1996;98:191-5.

5. Lougheed MD, Garvey N, Chapman KR, et al. The Ontario Asthma Regional Variation Study: emergency department visit rates and the relation to hospitalization rates. Chest 2006;129:909-17.

6. Global Initiative for Asthma (GINA). Global strategy for asthma management and prevention. Global Initiative for Asthma, 2011. http://www.ginasthma.org/

7. British Thoracic Society, Scottish Intercollegiate Guidelines Network. British guidelines on the management of asthma-a national clinical guideline. British Thoracic Society 2011 [cited 3 Jan 2011]. http://www.brit-thoracic.org.uk/clinical-information/ asthma/asthma-guidelines.aspx

8. Becker A, Bérubé D, Chad Z, et al. Canadian Pediatric Asthma Consensus Guidelines, 2003 (updated to December 2004): introduction. CMAJ 2005;173(Suppl 6):S12-14.

9. National Asthma Education and Prevention Program. Expert panel report 3: guidelines for the diagnosis and management of asthma. No. 07-4051. Bethesda, MD: National Institutes of Health, 2007.

10. Becker $A$, Lemiere $C$, Bérubé $D$, et al. Summary of recommendations from the Canadian Asthma Consensus Guidelines, 2004 and Canadian Pediatric Asthma Consensus Guidelines, 2003. CMAJ 2005;173(Suppl 6):S3-11.

11. Plotnick LH, Ducharme FM. Acute asthma in children and adolescents: should inhaled anticholinergics be added to B2-agonists? Am J Respir Med 2003;2:109-15.

12. Plotnick L, Ducharme FM. Should inhaled anticholinergics be added to beta2-agonists in acute pediatric asthma? A systematic review of randomized controlled trials. BMJ 1998;317:971-7.

13. Ducharme FM, Davis GM. Randomized controlled trial of ipratropium bromide and frequent low doses of salbutamol in the 
management of mild and moderate acute pediatric asthma. $J$ Pediatr 1998;133:479-85.

14. Bhogal S, McGillivray D, Bourbeau J, et al. Early administration of systemic corticosteroids reduces hospital admission rates in children with moderate and severe asthma exacerbation. Ann Emerg Med 2012;60:84-91.

15. Schuh S, Reisman J, Alshehri M, et al. A comparison of inhaled fluticasone and oral prednisone for children with severe acute asthma. N Engl J Med 2000;343:689-94.

16. Schuh S, Dick PT, Stephens D, et al. High-dose inhaled fluticasone does not replace oral prednisolone in children with mild to moderate acute asthma. Pediatrics 2006;118:644-50.

17. Dempsey OJ, Lipworth BJ. Intravenous montelukast in acute asthma: expensive aminophylline? [letter]. Thorax 2000;55:808-9.

18. Rowe $\mathrm{BH}$, Bretzlaff JA, Bourdon $\mathrm{C}$, et al. Intravenous magnesium sulfate treatment for acute asthma in the emergency department: a systematic review of the literature.[see comment]. Ann Emerg Med 2000;36:181-90

19. Ducharme FM, Chabot G, Polychronakos C, et al. Safety profile of frequent short courses of oral glucocorticoids in acute pediatric asthma: impact on bone metabolism, bone density, and adrenal function. Pediatrics 2003;111:376-83.

20. Kasper WJ, Howe PM. Fatal varicella after a single course of corticosteroids. Pediatr Infect Dis J 1990;9:729-32.

21. Panickar J, Lakhanpaul M, Lambert PC, et al. Oral prednisolone for preschool children with acute virus-induced wheezing. $N$ Engl $J$ Med 2009;360:329-38.

22. Chaudhuri R, Livingston E, McMahon AD, et al. Cigarette smoking impairs the therapeutic response to oral corticosteroids in chronic asthma. [see comment]. Am J Respir Crit Care Med 2003;168:1308-11.

23. Ducharme FM, Chalut D, Plotnick L, et al. The pediatric respiratory assessment measure: a valid clinical score for assessing acute asthma severity from toddlers to teenagers. J Pediatr 2008;152:476-80.

24. Ducharme FM, Zemek RL, Schuh S. Oral corticosteroids in children with wheezing. N Engl J Med 2009;360:1674.

25. Plint AC, Johnson DW, Patel $\mathrm{H}$, et al. Epinephrine and dexamethasone in children with bronchiolitis. [see comment]. N Engl J Med 2009;360:2079-89.

26. Corneli HM, Zorc JJ, Mahajan $\mathrm{P}$, et al. A multicenter, randomized, controlled trial of dexamethasone for bronchiolitis. $N$ Engl J Med 2007;357:331-9.

27. Weinberger M. Corticosteroids for first-time young wheezers: current status of the controversy. J Pediatr 2003;143:700-2.

28. Strunk RC. Defining asthma in the preschool-aged child. Pediatrics 2002;109:357-61.

29. Myers TR. Pediatric asthma epidemiology: incidence, morbidity, and mortality. Respir Care Clin N Am 2000;6:1-14.

30. Martinez FD, Wright AL, Taussig LM, et al. Asthma and wheezing in the first six years of life. The Group Health Medical Associates. N Engl J Med 1995;332:133-8.

31. Bacharier LB, Boner A, Carlsen $\mathrm{KH}$, et al. Diagnosis and treatment of asthma in childhood: a PRACTALL consensus report. Allergy 2008;63:5-34

32. Johnston NW, Johnston SL, Duncan JM, et al. The September epidemic of asthma exacerbations in children: a search for etiology. J Allergy Clin Immunol 2005;115:132-8.

33. Johnston SL, Pattemore PK, Sanderson G, et al. The relationship between upper respiratory infections and hospital admissions for asthma: a time-trend analysis. Am J Respir Crit Care Med 1996;154(3 Pt 1):654-60.

34. Bardin PG, Johnston SL, Pattemore PK. Viruses as precipitants of asthma symptoms. II. Physiology and mechanisms. Clin Exp Allergy 1992;22:809-22.

35. Cypcar D, Stark J, Lemanske RFJ. The impact of respiratory infections on asthma. Pediatr Clin North Am 1992;39:1259-76.

36. Ong ELC, Daggett $P$, Wiselka MJ, et al. Influenza and asthma. Lancet 1992;339:367-8.

37. Murray CS, Poletti G, Kebadze T, et al. Study of modifiable risk factors for asthma exacerbations: virus infection and allergen exposure increase the risk of asthma hospital admissions in children. Thorax 2006;61:376-82.

38. Heymann PW, Platts-Mills TA, Johnston SL. Role of viral infections atopy and antiviral immunity in the etiology of wheezing exacerbations among children and young adults. Pediatr Infect Dis J 2005;24(Suppl 11):S217-22.

39. Wark PA, Johnston SL, Moric I, et al. Neutrophil degranulation and cell lysis is associated with clinical severity in virus-induced asthma. Eur Respir J 2002;19:68-75.
40. Jartti T, Lehtinen P, Vanto T, et al. Evaluation of the efficacy of prednisolone in early wheezing induced by rhinovirus or respiratory syncytial virus. [Article]. Pediatr Infect Dis J 2006;25:482-8.

41. Jartti $T$, Lehtinen $P$, Vanto $T$, et al. Efficacy of prednisolone in children hospitalized for recurrent wheezing. Pediatr Allergy Immunol 2007;18:326-34.

42. Chalmers GW, MacLeod KJ, Little SA, et al. Influence of cigarette smoking on inhaled corticosteroid treatment in mild asthma. Thorax 2002;57:226-30.

43. Lazarus SC, Chinchilli VM, Rollings NJ, et al. Smoking affects response to inhaled corticosteroids or leukotriene receptor antagonists in asthma. [see comment]. Am J Respir Crit Care Med 2007;175:783-90

44. Chalmers GW, MacLeod KJ, Thomson L, et al. Smoking and airway inflammation in patients with mild asthma. Chest 2001;120: 1917-22.

45. Chilmonczyk BA, Salmun LM, Megathlin KN, et al. Association between exposure to environmental tobacco smoke and exacerbations of asthma in children. [see comments]. $N$ Engl J Med 1993;328:1665-9.

46. Kohler E, Sollich V, Schuster R, et al. Passive smoke exposure in infants and children with respiratory tract diseases. Hum Exp Toxicol 1999;18:212-17.

47. Chang MY, Hogan AD, Rakes GP, et al. Salivary cotinine levels in children presenting with wheezing to an emergency department. Pediatr Pulmonol 2000;29:257-63.

48. Karp I, O'Loughlin J, Paradis G, et al. Smoking trajectories of adolescent novice smokers in a longitudinal study of tobacco use. Ann Epidemiol 2005;15:445-52.

49. Gervais A, O'Loughlin J, Meshefedjian G, et al. Milestones in the natural course of onset of cigarette use among adolescents. [see comment]. CMAJ 2006;175:255-61.

50. Prokhorov AV, Winickoff JP, Ahluwalia JS, et al. Youth tobacco use: a global perspective for child health care clinicians. [Review] [132 refs]. Pediatrics 2006;118:e890-903.

51. Statistics Canada. 2002 Youth smoking survey: parent's questionnaire. 1-8. Government of Canada, 2004.

52. Clark SJ, Warner JO, Dean TP. Passive smoking amongst asthmatic children. Questionnaire or objective assessment? Clin Exp Allergy 1994;24:276-80.

53. Willers S, Axmon A, Feyerabend C, et al. Assessment of environmental tobacco smoke exposure in children with asthmatic symptoms by questionnaire and cotinine concentrations in plasma, saliva, and urine. J Clin Epidemiol 2000;53:715-21.

54. Phillips K, Bentley MC, Abrar M, et al. Low level saliva cotinine determination and its application as a biomarker for environmental tobacco smoke exposure. Hum Exp Toxicol 1999;18:291-6.

55. Etzel RA. A review of the use of saliva cotinine as a marker of tobacco smoke exposure. [Review] [45 refs]. Prev Med 1990;19:190-7.

56. Halterman JS, Borrelli B, Tremblay $P$, et al. Screening for environmental tobacco smoke exposure among inner-city children with asthma. Pediatrics 2008;122:1277-83.

57. Dhar P. Measuring tobacco smoke exposure: quantifying nicotine/ cotinine concentration in biological samples by colorimetry, chromatography and immunoassay methods. J Pharm Biomed Anal 2004;35:155-68.

58. Salpeter SR, Buckley NS, Ormiston TM, et al. Meta-analysis: effect of long-acting \{beta\}-agonists on severe asthma exacerbations and asthma-related deaths. Ann Intern Med 2006;144:904-12.

59. Ernst P, Mclvor A, Ducharme FM, et al. Safety and effectiveness of long-acting inhaled beta-agonist bronchodilators when taken with inhaled corticosteroids. Ann Intern Med 2006;145:692-4.

60. Bush A. Phenotype specific treatment of asthma in childhood. Paediatr Respir Rev 2004;5(Suppl A):S93-101.

61. Bush A. Practice imperfect-treatment for wheezing in preschoolers. N Engl J Med 2009;360:409-10.

62. Gibson PG, Norzila MZ, Fakes K, et al. Pattern of airway inflammation and its determinants in children with acute severe asthma. Pediatr Pulmonol 1999;28:261-70.

63. Wark PA, Gibson PG, Johnston SL. Exacerbations of asthma: addressing the triggers and treatments. Monaldi Arch Chest Dis 2001;56:429-35.

64. Gilbert SF. Developmental biology. 6th edn. Sunderland, MA: Sinauer Associated Inc, 2000

65. Hall JG. How is the progress in genetics relevant to children's health care. Paediatr Child Health 2004:9:213-14.

66. Hall JG. Individualized medicine. What the genetic revolution will bring to health care in the 21st century. [see comment]. Can Fam Phys 2003;49:12-13. 
67. Bouzigon $\mathrm{E}$, Corda $\mathrm{E}$, Aschard $\mathrm{H}$, et al. Effect of $17 \mathrm{q} 21$ variants and smoking exposure in early-onset asthma. [see comment]. $N$ Engl J Med 2008;359:1985-94.

68. Lima JJ, Thomason DB, Mohamed MHN, et al. Impact of genetic polymorphisms of the [beta]2-adrenergic receptor on albuterol bronchodilator pharmacodynamics[ast]. Clin Pharmacol Ther 1999;65:519-25.

69. Sharma S, Raby BA, Hunninghake GM, et al. Variants in TGFB1, dust mite exposure, and disease severity in children with asthma. Am J Respir Crit Care Med 2009;179:356-62.

70. Laing IA, de Klerk NH, Turner SW, et al. Cross-sectional and longitudinal association of the secretoglobin $1 \mathrm{~A} 1$ gene A38G polymorphism with asthma phenotype in the Perth Infant Asthma Follow-up cohort. Clin Exp Allergy 2009;39:62-71.

71. Zhou H, Alexis N, Almond M, et al. Influence of C-159 T SNP of the CD14 gene promoter on lung function in smokers. Respir Med 2009;103:1358-65.

72. Moffatt MF, Kabesch M, Liang L, et al. Genetic variants regulating ORMDL3 expression contribute to the risk of childhood asthma. Nature 2007:448:470-3.

73. Hayes JD, Flanagan JU, Jowsey IR. Glutathione transferases. [Review] [166 refs]. Ann Rev Pharmacol Toxicol 2005;45:51-88.

74. Sundberg K, Johansson AS, Stenberg G, et al. Differences in the catalytic efficiencies of allelic variants of glutathione transferase P1-1 towards carcinogenic diol epoxides of polycyclic aromatic hydrocarbons. Carcinogenesis 1998;19:433-6.

75. Tamer L, Calikoglu M, Ates NA, et al. Glutathione-S-transferase gene polymorphisms (GSTT1, GSTM1, GSTP1) as increased risk factors for asthma. Respirology 2004;9:493-8.

76. He JQ, Ruan J, Connett JE, et al. Antioxidant gene polymorphisms and susceptibility to a rapid decline in lung function in smokers. $A m$ $J$ Respir Crit Care Med 2002;166:323-8.

77. Wang C, Salam MT, Islam T, et al. Effects of in utero and childhood tobacco smoke exposure and beta2-adrenergic receptor genotype on childhood asthma and wheezing. Pediatrics 2008;122:e107-14

78. Martinez FD, Graves PE, Baldini M, et al. Association between genetic polymorphisms of the beta2-adrenoceptor and response to albuterol in children with and without a history of wheezing. J Clin Invest 1997:100:3184-8.

79. Tantisira KG, Lake S, Silverman ES, et al. Corticosteroid pharmacogenetics: association of sequence variants in CRHR with improved lung function in asthmatics treated with inhaled corticosteroids. Hum Mol Genet 2004;13:1353-9.

80. Tantisira KG, Hwang ES, Raby BA, et al. TBX21: a functional variant predicts improvement in asthma with the use of inhaled corticosteroids. Proc Natl Acad Sci USA 2004;101:18099-104.

81. Tantisira KG, Silverman ES, Mariani TJ, et al. FCER2: a pharmacogenetic basis for severe exacerbations in children with asthma. J Allergy Clin Immunol 2007;120:1285-91.

82. Dijkstra A, Postma DS, Bruinenberg M, et al. SERPINE1 -675 4G/ $5 \mathrm{G}$ polymorphism is associated with asthma severity and inhaled corticosteroid response. Eur Respir J 2011;38:1036-43.

83. Hawkins GA, Lazarus R, Smith RS, et al. The glucocorticoid receptor heterocomplex gene STIP1 is associated with improved lung function in asthmatic subjects treated with inhaled corticosteroids. J Allergy Clin Immunol 2009;123:1376-83.

84. Tantisira KG, Lasky-Su J, Harada M, et al. Genomewide association between GLCCl1 and response to glucocorticoid therapy in asthma. N Engl J Med 2011;365:1173-83.

85. Gibson PG. Use of induced sputum to examine airway inflammation in childhood asthma. [Review] [14 refs]. J Allergy Clin Immunol 1998;102:S100-1.

86. Gibson PG, Woolley KL, Carty K, et al. Induced sputum eosinophil cationic protein (ECP) measurement in asthma and chronic obstructive airway disease (COAD)[comment]. Clin Exp Allergy 1998;28:1081-8.

87. Thomson NC, Chaudhuri R, Livingston E. Active cigarette smoking and asthma. Clin Exp Allergy 2003;33:1471-5.

88. Pizzichini MM, Pizzichini E, Efthimiadis A, et al. Asthma and natural colds. Inflammatory indices in induced sputum: a feasibility study. Am J Respir Crit Care Med 1998;158:1178-84.

89. Pavord ID, Brightling CE, Woltmann G, et al. Non-eosinophilic corticosteroid unresponsive asthma. Lancet 1999;353:2213-14.

90. Pavord ID, Shaw DE, Gibson PG, et al. Inflammometry to assess airway diseases. Lancet 2008:372:1017-19.

91. Gibson PG, Simpson JL, Saltos N. Heterogeneity of airway inflammation in persistent asthma: evidence of neutrophilic inflammation and increased sputum interleukin-8. [comment]. Chest 2001;119:1329-36.

92. Simpson JL, Scott RJ, Boyle MJ, et al. Differential proteolytic enzyme activity in eosinophilic and neutrophilic asthma. Am J Respir Crit Care Med 2005;172:559-65.
93. Gibson PG, Saltos N, Borgas T. Airway mast cells and eosinophils correlate with clinical severity and airway hyperresponsiveness in corticosteroid-treated asthma.[erratum appears in J Allergy Clin Immunol 2001 Feb;107(2):223]. J Allergy Clin Immunol 2000;105:752-9.

94. Lowhagen O, Wever AMJ, Lusuardi M, et al. The inflammatory marker serum eosinophil cationic protein (ECP) compared with PEF as a tool to decide inhaled corticosteroid dose in asthmatic patients. Respir Med 2002;96:95-101.

95. Anonymous. Recommendations for standardized procedures for the on-line and off-line measurement of exhaled lower respiratory nitric oxide and nasal nitric oxide in adults and children-1999. This official statement of the American Thoracic Society was adopted by the ATS Board of Directors, July 1999. Am J Respir Crit Care Med 1999;160:2104-17.

96. Anonymous. Exhaled nitric oxide in asthma. In: Aerocrine $A B$, ed. Scientific backgrounder. Solna, Sweden: Aerocrine Inc, 2003:1-55.

97. Warke TJ, Fitch PS, Brown V, et al. Exhaled nitric oxide correlates with airway eosinophils in childhood asthma. Thorax 2002;57:383-7.

98. Baraldi $E$, de Jongste JC. Measurement of exhaled nitric oxide in children, 2001. Eur Respir J 2002;20:223-37.

99. DeNicola LR, Kissoon N, Duckworth LJ, et al. Exhaled nitric oxide as an indicator of severity of asthmatic inflammation. Pediatr Emerg Care 2000;16:290-5

100. Massaro AF, Gaston B, Kita D, et al. Expired nitric oxide levels during treatment of acute asthma. Am J Respir Crit Care Med 1995;152:800-3.

101. Nelson BV, Sears S, Woods J, et al. Expired nitric oxide as a marker for childhood asthma. J Pediatr 1997;130:423-7.

102. Berlyne GS, Parameswaran K, Kamada D, et al. A comparison of exhaled nitric oxide and induced sputum as markers of airway inflammation. J Allergy Clin Immunol 2000;106:638-44.

103. Gibson PG, Henry RL, Thomas P. Noninvasive assessment of airway inflammation in children: induced sputum, exhaled nitric oxide, and breath condensate. Eur Respir J 2000;16:1008-15.

104. van Mastrigt E, Gabriele C, de Jongste JC. Exhaled nitric oxide in infants - what is a nice test like FENO doing in a place like this? Semin Respir Crit Care Med 2007;28:264-71.

105. Gabriele C, de Benedictis F, de Jongste J. Exhaled nitric oxide measurements in the first 2 years of life: methodological issues, clinical and epidemiological applications. Ital J Pediatr 2009;35:21.

106. Deykin A, Massaro AF, Drazen JM, et al. Exhaled nitric oxide as a diagnostic test for asthma: online versus offline techniques and effect of flow rate. Am J Respir Crit Care Med 2002;165:1597-601.

107. Avital A, Uwyyed K, Berkman N, et al. Exhaled nitric oxide and asthma in young children. Pediatr Pulmonol 2001;32:308-13.

108. Barreto M, Villa MP, Martella S, et al. Off-line exhaled nitric oxide measurements in children. Pediatr Pulmonol 2001;32:159-67.

109. Ungar WJ, Coyte PC, Pharmacy Medication Monitoring Program Advisory Board. Prospective study of the patient-level cost of asthma care in children. Pediatr Pulmonol 2001;32:101-8.

110. Ducharme FM, Davis GM. Measurement of respiratory resistance in the emergency department: feasibility in young children with acute asthma. Chest 1997;111:1519-25.

111. Stevens MW, Gorelick MH. Short-term outcomes after acute treatment of pediatric asthma. Pediatrics 2001;107:1357-62.

112. Gorelick MH, Stevens MW, Schultz TR, et al. Performance of a novel clinical score, the Pediatric Asthma Severity Score (PASS), in the evaluation of acute asthma. Acad Emerg Med 2004;11:10-18

113. Gorelick MH, Stevens MW, Schultz T, et al. Difficulty in obtaining peak expiratory flow measurements in children with acute asthma. Pediatr Emerg Care 2004;20:22-6.

114. Ducharme FM, Davis GM. Respiratory resistance in the emergency department: a reproducible and responsive measure of asthma severity. Chest 1998;113:1566-72.

115. Ducharme FM, Davis GM, Ducharme GR. Pediatric reference values for respiratory resistance measured by forced oscillation. Chest 1998;113:1322-8.

116. Frei J, Jutla J, Kramer G, et al. Impulse oscillometry: reference values in children 100 to $150 \mathrm{~cm}$ in height and 3 to 10 years of age. Chest 2005:128:1266-73.

117. Chalut DS, Ducharme FM, Davis GM. The preschool respiratory assessment measure (PRAM): a responsive index of acute asthma severity. J Pediatr 2000;137:762-8.

118. Ducharme FM, Mendelson MJ, Klassen TP, et al. The Preschool Asthma Diary (PAD): a validated instrument for day-to-day monitoring of asthma severity in young children. Pediatric Academic Societies, 2007.

119. Ducharme FM, Lemire C, Noya FJ, et al. Preemptive use of high-dose fluticasone for virus-induced wheezing in young children. N Engl J Med 2009;360:339-53. 
120. Santanello NC, Demuro-Mercon C, Davies G, et al. Validation of a pediatric asthma caregiver diary. J Allergy Clin Immunol 2000;106:861-6.

121. Juniper EF, Price DB, Stampone PA, et al. Clinically important improvements in asthma-specific quality of life, but no difference in conventional clinical indexes in patients changed from conventional beclomethasone dipropionate to approximately half the dose of extrafine beclomethasone dipropionate. Chest 2002;121:1824-32.

122. Juniper EF, Guyatt GH, Ferrie PJ, et al. Measuring quality of life in asthma. Am Rev Respir Dis 1993;147:832-8.

123. Juniper EF, Guyatt GH, Feeny $\mathrm{DH}$, et al. Measuring quality of life in children with asthma. Qual Life Res 1996;5:35-46.

124. Kirshner B, Guyatt G. A methodological framework for assessing health indices. J Chronic Dis 1985;38:27-36.

125. Gerald LB, Sockrider MM, Grad R, et al. An official ATS workshop report: issues in screening for asthma in children. Proc Am Thorac Soc 2007; 4:133-41.

126. Beydon N, Davis SD, Lombardi E, et al. An official American Thoracic Society/European Respiratory Society statement: pulmonary function testing in preschool children. Am J Respir Crit Care Med 2007;175:1304-45.

127. Canadian Association of Emergency Physicians. Guidelines for emergency management of paediatric asthma. http://www.caep.ca/ template.asp?id=3272F9E47A064ED4820C829B15BB1BCD 2008 [cited 10 Aug 2010]. http://www.caep.ca/template.asp? id=3272F9E47A064ED4820C829B15BB1BCD

128. Ducharme FM, Davis GM, Noya F, et al. The asthma quiz for kidz: a validated tool to appreciate the level of asthma control in children Can Respir J 2004;11:541-6.

129. Raymond F, Carbonneau J, Boucher N, et al. Comparison of automated microarray detection with real-time PCR assays for detection of respiratory viruses in specimens obtained from children. J Clin Microbiol 2009;47:743-50.

130. Seifert JA, Ross CA, Norris JM. Validation of a five-question survey to assess a child's exposure to environmental tobacco smoke. Ann Epidemiol 2002;12:273-7.

131. O'Loughlin J, Tarasuk J, Difranza J, et al. Reliability of selected measures of nicotine dependence among adolescents. Ann Epidemiol 2002;12:353-62.
132. Dulucq S, St-Onge G, Gagne V, et al. DNA variants in the dihydrofolate reductase gene and outcome in childhood ALL. Blood 2008;111:3692-700.

133. Labuda D, Krajinovic M, Richer C, et al. Rapid detection of CYP1A1, CYP2D6, and NAT variants by multiplex polymerase chain reaction and allele-specific oligonucleotide assay. Anal Biochem 1999;275:84-92.

134. Gibson PG, Grootendor DC, Henry RL, et al. Sputum induction in children. [Review] [18 refs]. Eur Respir J Suppl 2002;37:44s-6s.

135. Twaddell SH, Gibson PG, Carty K, et al. Assessment of airway inflammation in children with acute asthma using induced sputum. Eur Respir J 1996;9:2104-8.

136. Wark PA, Simpson JL, Hensley MJ, et al. Safety of sputum induction with isotonic saline in adults with acute severe asthma. Clin Exp Allergy 2001;31:1745-53.

137. Gibson PG, Norzila MZ, Fakes K, et al. Pattern of airway inflammation and its determinants in children with acute severe asthma. Pediatr Pulmonol 1999;280:261-70.

138. McGillivray DL, Chalut D, Plotnick $L$, et al. Impact on admission rates of evidenced-based asthma guidelines in the real life of the emergency department. Pediatr Res 2004;55:24A.

139. Ducharme FM, Zemek RL, Chalut DS, et al. Written action plan in pediatric emergency room improves asthma prescribing, adherence and control. Am J Respir Crit Care Med 2011;183:195-203.

140. Holgate ST. [Respiratory inflammation]. [French]. Allerg Immunol 1997;29:75-6; discussion 82.

141. Refabert L, Mahut B, de Blic J, et al. [Acute viral respiratory infections and asthma]. [French]. Rev Prat 1996;46:2077-82.

142. Demidenko E. Sample size and optimal design for logistic regression with binary interaction. Stat Med 2008;27:36-46.

143. Hsieh FY, Bloch DA, Larsen MD. A simple method of sample size calculation for linear and logistic regression. Stat Med 1998;17:1623-34.

144. Rowe BH, Spooner C, Ducharme FM, et al. Early emergency department treatment of acute asthma with systemic corticosteroids. Cochrane Database Syst Rev 2001;(1):CD002178.

145. Smith M, lqbal S, Elliott TM, et al. Corticosteroids for hospitalised children with acute asthma. Cochrane Database Syst Rev 2003;(2) CD002886. 